\title{
Effect of Ginseng Saponins on Enhanced Dopaminergic Transmission and Locomotor Hyperactivity Induced by Nicotine
}

\author{
Sang Eun Kim*,', Insop Shim², June-Key Chung' and Myung Chul Lee' \\ 'Department of Nuclear Medicine, Seoul National University College of Medicine, Seoul, Korea; ${ }^{2}$ Department of Integrative Medicine, College of \\ Medicine, The Catholic University of Korea, Seoul, Korea
}

\begin{abstract}
Several studies have shown that behavioral hyperactivity induced by psychomotor stimulants is prevented by ginseng saponins. In an attempt to investigate whether the effect of ginseng saponins is through their inhibitory action on the enhanced dopaminergic transmission by psychomotor stimulants, we examined the effects of ginseng total saponin (GTS) presynaptically on nicotine-induced dopamine (DA) release in the striatum of freely moving rats using in vivo microdialysis technique and postsynaptically on the in vitro and in vivo binding of $\left[{ }^{3} \mathrm{H}\right]$ raclopride to $\mathrm{DA} \mathrm{D}_{2}$ receptors. Also, we examined the effects of GTS on nicotine-induced locomotor hyperactivity and on nicotine-induced Fos protein expression in the nucleus accumbens and striatum. Systemic pretreatment with GTS (I00 and $400 \mathrm{mg} / \mathrm{kg}$, intraperitoneally (i.p.)) resulted in a dose-dependent inhibition of locomotor hyperactivity induced by nicotine. GTS decreased nicotine-induced DA release in the striatum in a dose-dependent manner. However, GTS had no effects on resting levels of locomotor activity and extracellular DA in the striatum. GTS inhibited the in vitro binding of $\left[{ }^{3} \mathrm{H}\right]$ raclopride to rat striatal membranes with an $I_{50}$ of $5.14 \pm 1.09 \mu \mathrm{M}$. High doses of GTS (400 and $800 \mathrm{mg} / \mathrm{kg}$, i.p.) resulted in decreases in the in vivo binding of [ $\left.{ }^{3} \mathrm{H}\right]$ raclopride in the striatum. GTS decreased nicotine-induced Fos protein expression in the nucleus accumbens and striatum, reflecting the inhibition by GTS of nicotine-induced enhancement of dopaminergic transmission. The results of the present study suggest that GTS acts not only on dopaminergic neurons directly or indirectly to prevent nicotine-induced DA release but also postsynaptically by binding to DA $D_{2}$ receptors. This may explain the blocking effect of GTS on behavioral activation induced by nicotine and conceivably by other psychostimulants. Our data raise the possibility that GTS, by attenuating nicotine-induced enhancement of dopaminergic transmission, may prove to be a useful therapeutic agent for nicotine addiction and warrant further investigation on its effect on nicotine's rewarding property.

Neuropsychopharmacology (2006) 31, 17|4-1721. doi:I0.1038/sj.npp.1300945; published online 26 October 2005
\end{abstract}

Keywords: ginseng total saponin; nicotine; dopamine release; dopamine $\mathrm{D}_{2}$ receptor; Fos protein; locomotor activity

\section{INTRODUCTION}

Evidence suggests that nicotine, the neuroactive compound of tobacco, has common neurochemical as well as behavioral properties with other addictive drugs such as cocaine and amphetamine (Henningfield and Heishman, 1995; Pontieri et al, 1996). It is well documented that nicotine stimulates dopamine (DA) release in the nucleus accumbens and striatum (Imperato et al, 1986; Damsma et al, 1989; Toth et al, 1992; Benwell and Balfour, 1994;

*Correspondence: Dr SE Kim, Department of Nuclear Medicine, Seoul National University Bundang Hospital, 300 Gumi-dong, Bundang-gu, Seongnam-si, Gyeonggi-do, 463-707, Korea, Tel: + 8231787 7671, Fax: +82 31 78740 I8, E-mail: kse@snu.ac.kr

Received 18 March 2005; revised 24 August 2005; accepted 15 September 2005

Online publication: 20 September 2005 at http://www.acnp.org/ citations/Npp092005050190/default.pdf
Nisell et al, 1994a; Pontieri et al, 1996; Mirza et al, 1996; Marshall et al, 1997). This property has been related to the addictive and behavioral properties of nicotine (Benwell and Balfour, 1992; Corrigall et al, 1992; Di Chiara and Imperato, 1988).

Ginseng, the root of Panax ginseng CA Meyer, has been used widely as a herbal medicine across the world. Many investigators have reported its chemical and pharmacological properties and saponin appears to be responsible for most of the pharmacological effects of ginseng. Behavioral studies have suggested that ginseng saponins or ginsenosides may act on the central dopaminergic system. Pretreatment with ginseng saponins or ginseng extract was able to block the development of behavioral sensitization induced by cocaine (Kim et al, 1995a), methamphetamine (Tokuyama et al, 1992), and morphine (Kim et al, 1995b). The conditioned place preference induced by these drugs was also antagonized by ginseng saponins (Kim et al, 
1996a, b). Also, it has been shown that ginseng saponins inhibit nicotine-induced hyperlocomotion, behavioral sensitization, and conditioned place preference (Kim and Kim, 1999). However, the neurochemical mechanisms underlying the behavioral effects of ginseng saponins are not well understood.

Convergent evidence suggests that drugs of abuse exert their locomotor stimulating and rewarding effects by increasing dopaminergic transmission. Therefore, it seems possible that the behavioral effects of ginseng saponins reflect their blockade of enhanced dopaminergic transmission by those drugs. In an attempt to examine this hypothesis, we investigated the following: (1) the effect of ginseng total saponin (GTS) on nicotine-induced locomotor hyperactivity; (2) the effect of GTS presynaptically on nicotine-induced DA release in the striatum of freely moving rats using in vivo microdialysis technique; (3) the effect of GTS postsynaptically on the in vitro and in vivo binding of $\left[{ }^{3} \mathrm{H}\right]$ raclopride to $\mathrm{DA}_{2}$ receptors; and (4) the effect of GTS on nicotine-induced Fos protein expression in the nucleus accumbens and striatum.

\section{MATERIALS AND METHODS}

\section{Animals}

Male Sprague-Dawley rats, weighing 280-320 g, were used for in vivo microdialysis, behavioral, in vitro receptor binding, and immunohistochemical studies. Male ICR mice (25-30 g) were used for in vivo binding studies. The animals were group-housed in light-, temperature-, and humiditycontrolled animal quarters with food and water available ad libitum. All procedures involving animal use were in strict accordance with the NIH Guide for the Care and Use of Laboratory Animals and were approved by the Seoul National University Hospital Animal Care and Use Committee.

\section{Drugs and Chemicals}

(-)-Nicotine hydrogen tartrate was purchased from Sigma Chemical Co. (St Louis, MO). GTS was a gift from Korea Ginseng and Tobacco Research Institute (Daejeon, Korea). GTS (a characterized saponin mixture quantitatively containing nine major glycosides known as ginsenosides $\left(\mathrm{Rb}_{1}\right.$ $20.14 \%, \mathrm{Rb}_{2} 10.19 \%$, Rc $11.34 \%$, Rd $4.63 \%$, Re $12.27 \%$, Rf 3.01\%, $\mathrm{Rg}_{1} 16.44 \%, \mathrm{Rg}_{2} 2.01 \%$, and $\mathrm{Rg}_{3} 2.64 \%$ ) and other minor ginsenosides and components (17.33\%), according to an HPLC method of Ko et al (1992), from P. ginseng) was extracted and purified using the method of Ando et al (1971). $\left[{ }^{3} \mathrm{H}\right]$ raclopride $(79.3 \mathrm{Ci} / \mathrm{mmol})$ was purchased from New England Nuclear (Boston, MA).

\section{Surgery and Microdialysis Procedures}

Rats were anesthetized with sodium pentobarbital $(50 \mathrm{mg} /$ $\mathrm{kg}$, intraperitoneally (i.p.)). Using aseptic techniques, a guide cannula (CMA/12, CMA Microdialysis, Solna, Sweden) aimed to terminate in the dorsal striatum (AP 1.0, L 3.2 from bregma; H 3.0 from dura) (Paxinos and Watson, 1986) was stereotaxically implanted and attached to the skull using skull screws and dental cement. The cannula was then closed with a tight-fitting stainless-steel obturator. The microdialysis was performed in freely moving rats. Following 3-day recovery, a $4 \mathrm{~mm}$ microdialysis probe (CMA/12, CMA Microdialysis) connected via a dual liquid swivel to a syringe pump was inserted into the guide cannula and perfused with an artificial cerebrospinal fluid $(145 \mathrm{mM}$ $\mathrm{NaCl}, 2.7 \mathrm{mM} \mathrm{KCl}, 1.2 \mathrm{mM} \mathrm{CaCl}, 1.0 \mathrm{mM} \mathrm{MgCl}_{2}, 2.0 \mathrm{mM}$ $\mathrm{Na}_{2} \mathrm{HPO}_{4} ; \mathrm{pH} 7.4$ ) at a constant rate of $1.5 \mu \mathrm{l} / \mathrm{min}$. Dialysate samples were collected during 20 min sampling intervals via outlet tubing connected to a microfraction collector (CMA Microdialysis). The position of the probes was verified by histological examination at the end of experiments.

\section{Analytical Procedures}

The dialysate (injection volume $30 \mu \mathrm{l}$ ) was assayed for DA using HPLC coupled to an ESA Coulochem II 5200A electrochemical detection system with an oxidation potential of $+320 \mathrm{mV}$. The detector was equipped with a highperformance analytical cell (ESA model 5014), which is tailored for use in microdialysis applications. The mobile phase was composed of $75 \mathrm{mM}$ monobasic sodium phosphate, $0.1 \mathrm{mM}$ EDTA, $1.4 \mathrm{mM}$ octanesulfonic acid and $10 \%$ acetonitrile, and adjusted to $\mathrm{pH} 3.2$ with HPLC grade phosphoric acid. The separation of monoamine metabolites was performed on a Waters Nova-Pak C-18 column $(4 \mu \mathrm{m}$, $150 \times 3.9 \mathrm{~mm})$. The flow rate of the system was $1.0 \mathrm{ml} / \mathrm{min}$. DA in dialysates was expressed as a percentage of three baseline samples collected immediately before nicotine treatment.

\section{Drug Treatments}

Nicotine was dissolved in the artificial cerebrospinal fluid to the concentration of $10 \mathrm{mM}$ (expressed as free base) and infused for $60 \mathrm{~min}$ locally into the striatum through the dialysis probe. GTS (100 and $400 \mathrm{mg} / \mathrm{kg}$, dissolved in saline) was injected i.p. 60 min before nicotine was administered.

\section{Measurement of Locomotor Activity}

The effect of GTS on nicotine-induced behavioral hyperactivity was evaluated in rats by measuring locomotor activity using a stabilimeter interfaced to a personal computer system. The stabilimeter, in which a loudspeaker is used both as platform and transducer, was constructed based on the design described by Parreno et al (1985). In our preliminary studies, this equipment provided a good reproducibility and a high sensitivity for measuring locomotor activity of small animals. Each animal was placed on the stabilimeter and after a habituation period of $60 \mathrm{~min}$ followed by the measurement of baseline activity for $60 \mathrm{~min}$, nicotine $(10 \mathrm{mM})$ was infused for $60 \mathrm{~min}$ locally into the striatum through the dialysis probe. Control animals were implanted with the dialysis probe and infused with the artificial cerebrospinal fluid. Locomotor activity was measured during $20 \mathrm{~min}$ intervals for a total of $180 \mathrm{~min}$ after the administration of nicotine. GTS (100 and $400 \mathrm{mg} / \mathrm{kg}$ ) was injected i.p. 60 min prior to nicotine. 


\section{In Vitro Inhibition Experiments}

Inhibition by GTS of the in vitro binding of $\left[{ }^{3} \mathrm{H}\right]$ raclopride to striatal $\mathrm{DA}_{2}$ receptors was investigated. Rats were killed by rapid decapitation. The striata were quickly dissected, frozen on a block of dry ice, and stored at $-70^{\circ} \mathrm{C}$ until needed. The binding of $\left[{ }^{3} \mathrm{H}\right]$ raclopride to rat striatal membranes was conducted as described by Lidow et al (1989). Briefly, tissues were homogenized in ice-cold $50 \mathrm{mM}$ Tris $\cdot \mathrm{HCl}$ buffer ( $\mathrm{pH}$ 7.4) and centrifuged at $45000 \mathrm{~g}$ for $10 \mathrm{~min}$. The resulting pellet was resuspended in 20 volumes of buffer, recentrifuged, and resuspended at $10 \mathrm{mg}$ wet weight $/ \mathrm{ml}$ of incubation buffer $(50 \mathrm{mM}$ Tris $\cdot \mathrm{HCl}$ buffer $(\mathrm{pH}$ 7.4) containing $120 \mathrm{mM} \mathrm{NaCl}, 5 \mathrm{mM} \mathrm{KCl}, 2 \mathrm{mM} \mathrm{CaCl}_{2}$, and $\left.1 \mathrm{mM} \mathrm{MgCl}_{2}\right)$. Inhibition assays of $\left[{ }^{3} \mathrm{H}\right]$ raclopride were performed using a fixed concentration of $\left[{ }^{3} \mathrm{H}\right]$ raclopride $(4.3 \mathrm{nM})$ and increasing concentrations of GTS (10 pM to $10 \mathrm{mM})$. The incubations were conducted in a final volume of $250 \mu \mathrm{l}$ for $30 \mathrm{~min}$ at $20-22^{\circ} \mathrm{C}$. The incubation was terminated by rapid filtration through Whatman GF/B filters previously soaked in $0.05 \%$ polyethylenimine using a Brandel MP-48LT filtering manifold (Gaithersburg, MD). The radioactivity trapped in the filters was measured in a liquid scintillation counter (Tri-Carb 2500 TR, Packard Instrument Co., Meriden, CT) after addition of $5 \mathrm{ml}$ Aquassure scintillator (Packard). Nonspecific binding was defined using $1 \mu \mathrm{M}(+)$-butaclamol.

\section{In Vivo Binding Experiments}

The effect of GTS on the in vivo binding of $\left[{ }^{3} \mathrm{H}\right]$ raclopride was investigated by pretreating mice with different doses of GTS $(50-800 \mathrm{mg} / \mathrm{kg}$, i.p.) $60 \mathrm{~min}$ before injection of $\left[{ }^{3} \mathrm{H}\right]$ raclopride. $\left[{ }^{3} \mathrm{H}\right]$ raclopride $(1 \mu \mathrm{Ci}$ in $0.2 \mathrm{ml}$ saline $)$ was injected intravenously into a tail vein, and 15 min later, the animals were killed by cervical dislocation. Different brain regions were immediately dissected on ice, weighed and placed into glass vials. After digestion of the tissues with Soluene-350 (Packard), $10 \mathrm{ml}$ of Formula 989 scintillator (Packard) was added and the samples counted in a liquid scintillation counter.

\section{Fos Immunohistochemistry}

The effect of GTS on nicotine-induced Fos protein expression in dopaminergic target areas was examined. Rats received subcutaneous (s.c.) injection of nicotine $(0.4 \mathrm{mg} / \mathrm{kg}$; expressed as free base) $2 \mathrm{~h}$ before anesthesia (ketamine $80 \mathrm{mg} / \mathrm{kg}$, i.p. plus xylazine $10 \mathrm{mg} / \mathrm{kg}$, i.p.). GTS $(100 \mathrm{mg} / \mathrm{kg})$ was administered i.p. $60 \mathrm{~min}$ before nicotine injection. Rats were transcardially perfused with ice-cold $0.1 \mathrm{M}$ phosphate buffered saline (PBS), $\mathrm{pH} 7.4$ followed by $4 \%$ paraformaldehyde in $0.1 \mathrm{M}$ PBS. The brains were removed and post-fixed with the same fixative for $2 \mathrm{~h}$ at room temperature and immersed in a $20 \%$ sucrose solution overnight at $4{ }^{\circ} \mathrm{C}$. The frozen tissue was cut into $30 \mu \mathrm{m}$ thick sections on a cryostat. Coronal sections were rinsed in PBS $(2 \times 5 \mathrm{~min})$ and placed in $0.3 \% \mathrm{H}_{2} \mathrm{O}_{2}$ in methanol for $15 \mathrm{~min}$ and then washed in PBS $(3 \times 5 \mathrm{~min})$. The sections were preincubated in a $2 \%$ normal goat serum (DAKO, Glostrup, Denmark) in PBS-T (0.1\% Triton X-100 in PBS) for 40 min to block nonspecific staining and then incubated with the primary antibody (rabbit polyclonal Fos antibody, Oncogene Research, Cambridge, MA) diluted in $1: 1000$ for $48 \mathrm{~h}$ at $4{ }^{\circ} \mathrm{C}$. The sections were washed in PBS-T $(3 \times 5 \mathrm{~min})$ and incubated for $1 \mathrm{~h}$ with biotinylated goat anti-rabbit secondary antibody (Vector Laboratories, Burlingame, CA). After washing with PBS $(3 \times 5 \mathrm{~min})$, the sections were incubated for $1 \mathrm{~h}$ with PBS-T containing avidin-biotinylated horseradish peroxidase complex (1:100, Vector Laboratories). The sections were washed in PBS $(3 \times 5 \mathrm{~min})$ and then rinsed for $10 \mathrm{~min}$ in $0.175 \mathrm{M}$ sodium acetate buffer ( $\mathrm{pH} 7.5$ ). The immunoreactive complex was revealed using diaminobenzidine (DAB) and nickel sulfate $\left(\mathrm{NiSO}_{4}\right)(0.2 \mathrm{mg} / \mathrm{ml}$ $\mathrm{DAB}, 25 \mathrm{mg} / \mathrm{ml} \mathrm{NiSO}_{4}$ and $0.83 \mu \mathrm{l} / \mathrm{ml} 3 \% \mathrm{H}_{2} \mathrm{O}_{2}$ in $0.175 \mathrm{M}$ sodium acetate) for $4 \mathrm{~min}$. Sections were washed with PBS twice and mounted on silane-coated slides, air-dried, dehydrated through graded ethanols into xylene, and coverslipped with Permount (Fisher Scientific, Pittsburgh, PA). No Fos-like immunoreactivity has been observed when the primary antibody was omitted. The number of Fospositive nuclei were counted by using the IBAS image analysis system (Zeiss, Germany) within a squared field area of $210 \times 210 \mu \mathrm{m}$ for the nucleus accumbens and $420 \times 420 \mu \mathrm{m}$ for the striatum using $\times 200$ magnifications. The mean value of the three to six sections was calculated from each selected region.

\section{Statistical Analysis}

Unless otherwise stated, values are expressed as mean \pm SEM. Data were analyzed by one-way analysis of variance (ANOVA) or two-way ANOVA (drug treatment $\times$ time) with repeated measures on the time factor. The origin of significant effects was further examined by post hoc comparisons using the Bonferroni technique.

\section{RESULTS}

\section{Effect of GTS on Nicotine-Induced Locomotor Hyperactivity}

Figure 1 shows the effect of GTS on nicotine-induced hyperlocomotion. Local infusion of nicotine $(10 \mathrm{mM})$ into the striatum via the dialysis probe increased the locomotor activity (maximal response $=589 \%$ of controls). This effect was attenuated by systemic pretreatment with GTS. An ANOVA indicated a significant effect of drug treatments $\left(\mathrm{F}_{3,12}=8.7, p<0.005\right)$. Post hoc comparisons revealed that GTS attenuated the nicotine-induced hyperlocomotion in a dose-dependent manner. GTS (100 and $400 \mathrm{mg} / \mathrm{kg}$, i.p.) decreased the nicotine-induced maximal locomotor activity by $37 \%(p<0.01)$ and $58 \%(p<0.005)$, respectively. However, GTS (100 and $400 \mathrm{mg} / \mathrm{kg}$, i.p.) had no effect on resting levels of locomotor activity until $180 \mathrm{~min}$ after injection $\left(\mathrm{F}_{2,9}=0.7, p=\mathrm{NS}\right)$ (Figure 3 ).

\section{Effect of GTS on Nicotine-Induced DA Release}

Figure 2 shows the effect of GTS on nicotine-induced changes in extracellular DA in the striatum. Local infusion of nicotine $(10 \mathrm{mM})$ into the striatum produced an increase in extracellular DA in the striatum (maximal response $=500 \pm 78 \%$ of basal levels). This effect was 


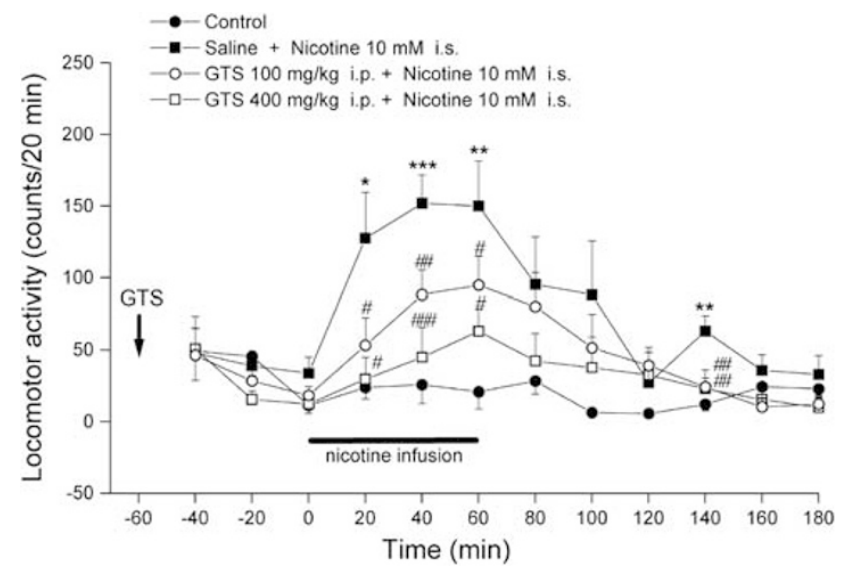

Figure I Effect of GTS on nicotine-induced hyperlocomotion. Nicotine $(10 \mathrm{mM})$ was infused intrastriatally (i.s.) for $60 \mathrm{~min}$ beginning at time 0 . GTS ( 100 and $400 \mathrm{mg} / \mathrm{kg}$ ) was administered i.p. $60 \mathrm{~min}$ before nicotine infusion. Results are means \pm SEM of four independent experiments. $* p<0.05$, ${ }^{* *} p<0.005$, ${ }^{* * * *} p<0.00$ I vs the control group; ${ }^{\#} p<0.05$, ${ }^{\# \#} p<0.01$, $\# \# \#<0.005$ vs the saline plus nicotine group.

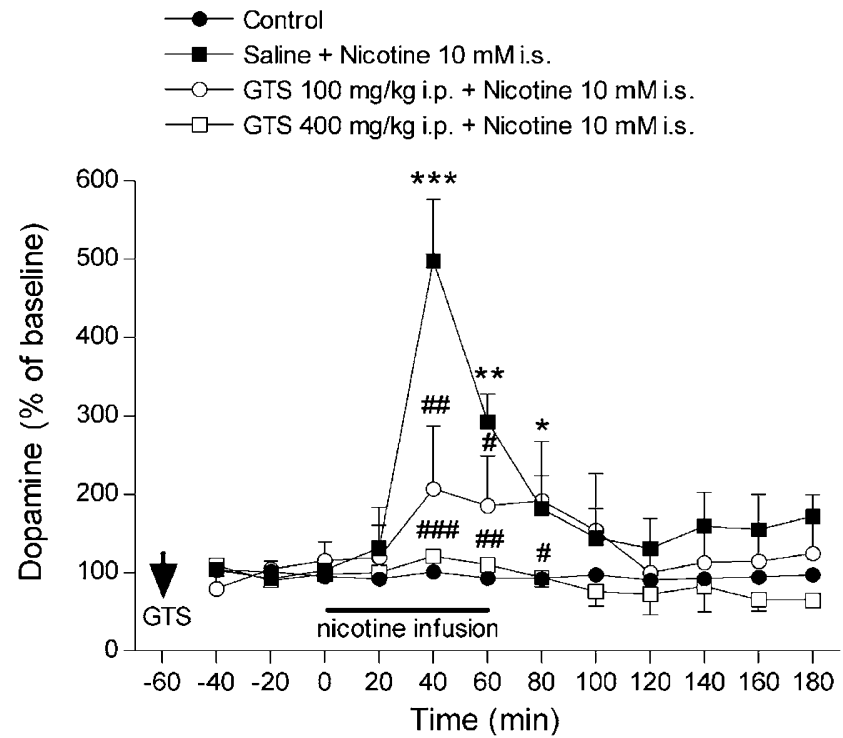

Figure 2 Effect of GTS on nicotine-induced changes in extracellular DA in the striatum. Nicotine $(10 \mathrm{mM})$ was infused intrastriatally (i.s.) for $60 \mathrm{~min}$ beginning at time 0 . GTS ( 100 and $400 \mathrm{mg} / \mathrm{kg}$ ) was administered i.p. $60 \mathrm{~min}$ before nicotine infusion. Results are expressed as a percentage of three baseline samples and are means \pm SEM of 4-6 independent experiments. ${ }^{*} p<0.05$, ${ }^{*} p<0.005$, ${ }^{*} * * * 0.00$ I vs the control group; ${ }^{\#} p<0.05$,

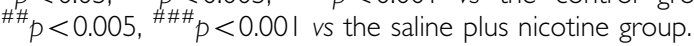

attenuated by GTS. An ANOVA indicated a significant effect of drug treatments $\left(\mathrm{F}_{3,16}=9.2, p<0.001\right)$. Post hoc comparisons revealed that GTS attenuated the nicotineinduced DA release in a dose-dependent manner. GTS (100 and $400 \mathrm{mg} / \mathrm{kg}$, i.p.) inhibited the nicotine-induced maximal DA response by $58 \%(p<0.005)$ and $76 \%$ $(p<0.001)$, respectively. However, GTS $(100$ and $400 \mathrm{mg} /$ $\mathrm{kg}$, i.p.) had no effect on resting levels of extracellular DA in the striatum until $180 \mathrm{~min}$ after injection $\left(\mathrm{F}_{2,11}=0.9\right.$, $p=\mathrm{NS}$ ) (Figure 3).

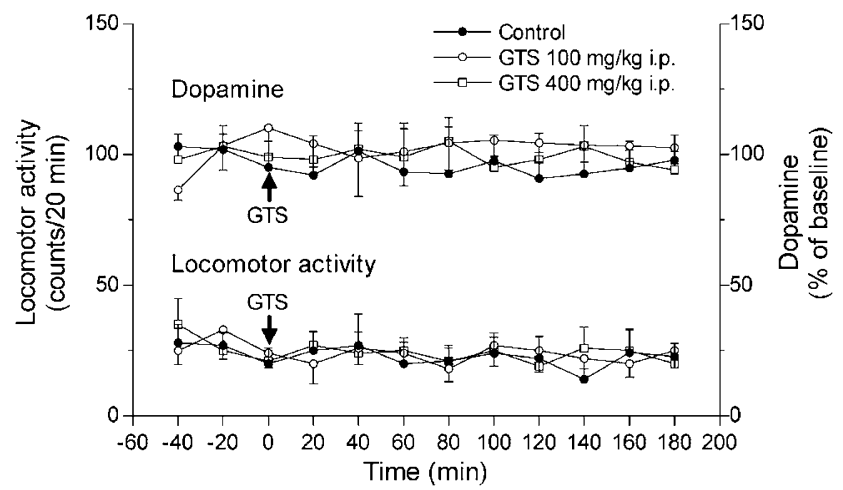

Figure 3 Effect of GTS on resting levels of locomotor activity and extracellular DA in the striatum. GTS ( 100 and $400 \mathrm{mg} / \mathrm{kg}$ ) was administered i.p. at time 0 . There were no significant differences in resting levels of locomotor activity and extracellular DA between control and GTS-treated animals. Results are means \pm SEM of 4-5 independent experiments.

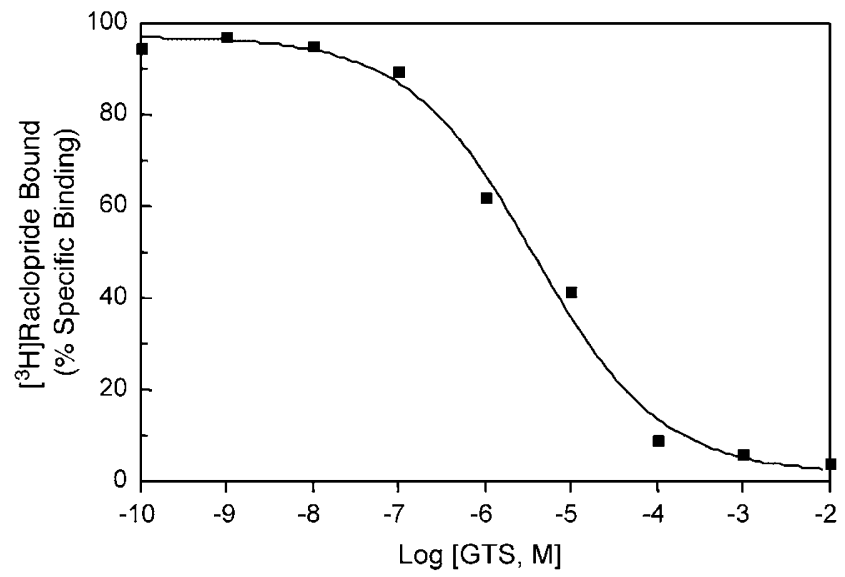

Figure 4 Inhibition of specific $\left[{ }^{3} \mathrm{H}\right]$ raclopride binding by GTS in rat striatal membranes. Presented are the results of a representative experiment; points are the means of triplicate determinations.

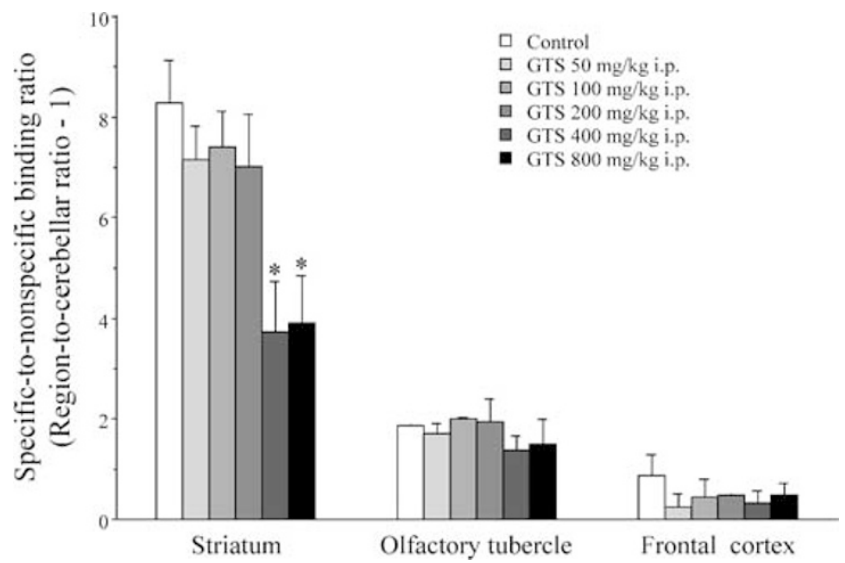

Figure 5 Effect of GTS on the in vivo binding of $\left[{ }^{3} \mathrm{H}\right]$ raclopride in brain regions. GTS $(50-800 \mathrm{mg} / \mathrm{kg})$ was administered i.p. $90 \mathrm{~min}$ before intravenous injection of $\left[{ }^{3} \mathrm{H}\right]$ raclopride. In vivo $\left[{ }^{3} \mathrm{H}\right]$ raclopride binding was measured I 5 min after radiotracer injection. Results are expressed as ratios of specific-to-nonspecific binding (region-to-cerebellar ratio-I) and are means $\pm S D ; n=4$ for each group. ${ }^{*} p<0.000$ I. 
Nucleus accumbens
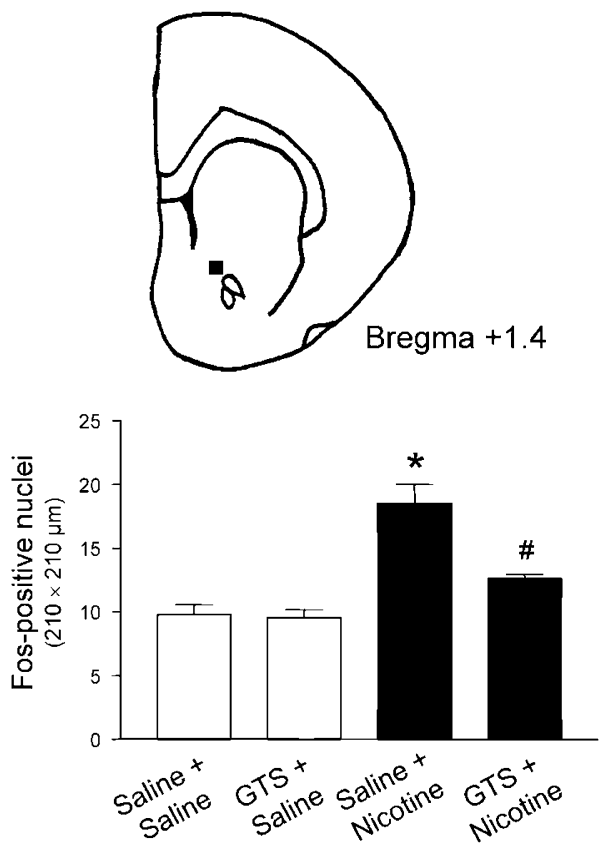

Striatum
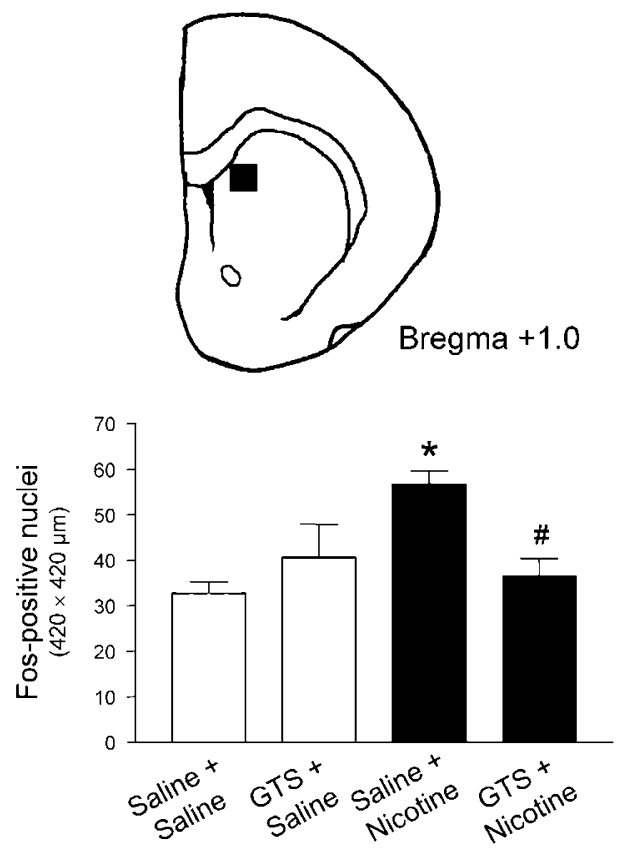

Figure 6 Effect of GTS on nicotine-induced Fos protein expression in the nucleus accumbens and striatum, with schematic drawings indicating areas in which Fos-positive nuclei were counted. GTS ( $100 \mathrm{mg} / \mathrm{kg}$ ) was administered i.p. $60 \mathrm{~min}$ before nicotine injection ( $0.4 \mathrm{mg} / \mathrm{kg}$, s.c.). Results are means \pm SEM of four independent experiments. ${ }^{*} p<0.05$ vs the saline plus saline group, ${ }^{\#} p<0.05$ vs the saline plus nicotine group.

\section{Effect of GTS on the In Vitro Binding of $\left[{ }^{3} \mathrm{H}\right]$ raclopride}

GTS inhibited the binding of $\left[{ }^{3} \mathrm{H}\right]$ raclopride to striatal membranes with an $\mathrm{IC}_{50}$ of $5.14 \pm 1.09 \mu \mathrm{M}$ (mean \pm SEM of five independent experiments) (Figure 4).

\section{Effect of GTS on the In Vivo Binding of $\left[{ }^{3} \mathrm{H}\right]$ raclopride}

Figure 5 shows the effect of GTS on the in vivo binding of $\left[{ }^{3} \mathrm{H}\right]$ raclopride in different brain regions. Doses of $50-$ $200 \mathrm{mg} / \mathrm{kg}$ GTS resulted in 11-15\%, but not significant decreases in the in vivo binding of $\left[{ }^{3} \mathrm{H}\right]$ raclopride in the striatum. Increasing the dose of GTS to 400 and $800 \mathrm{mg} / \mathrm{kg}$ led to abrupt decreases in striatal $\left[{ }^{3} \mathrm{H}\right]$ raclopride binding by $55 \%(p<0.0001)$ and 53\% $(p<0.0001)$, respectively. Regional analysis of the binding data indicated that the maximal effect of GTS on the in vivo binding of $\left[{ }^{3} \mathrm{H}\right]$ raclopride occurred in the striatum, a region rich in $\mathrm{DA} \mathrm{D}_{2}$ receptors.

\section{Effect of GTS on Nicotine-Induced Fos Protein Expression}

Figure 6 shows the effect of GTS on nicotine-induced Fos protein expression in dopaminergic target areas. Nicotine $(0.4 \mathrm{mg} / \mathrm{kg}$, s.c.) increased the number of Fos-positive nuclei in the nucleus accumbens and striatum by $89 \%(p<0.05)$ and $73 \%(p<0.05)$, respectively. GTS $(100 \mathrm{mg} / \mathrm{kg}$, i.p. $)$ decreased the nicotine-induced Fos protein expression in the nucleus accumbens and striatum by $32 \%(p<0.05)$ and $36 \%(p<0.05)$, respectively. GTS did not influence resting levels of Fos-positive nuclei in the nucleus accumbens and striatum (see Figure 6).

\section{DISCUSSION}

This study demonstrated that systemic pretreatment with GTS inhibits nicotine-induced hyperlocomotion and striatal DA release in a dose-dependent manner. As behavioral hyperactivity produced by nicotine is associated with an increase in DA release in the striatum as well as in the nucleus accumbens (Shim et al, 2001), the inhibitory action of GTS on nicotine-induced DA release in the striatum explains, at least in part, its blocking effect on behavioral activation produced by nicotine. We also found that GTS binds, with a modest affinity, to DA $\mathrm{D}_{2}$ receptors both in vitro and in vivo. Because GTS had no effect on resting levels of extracellular DA, the inhibition by GTS of in vivo binding of $\left[{ }^{3} \mathrm{H}\right]$ raclopride is not due to changes in synaptic DA levels. We do not know the function of GTS at DA $\mathrm{D}_{2}$ receptor sites. In the present study, the dose-dependent effect of GTS against intrastriatal infusion of nicotine was greater for the reduction of locomotor activity $(57 \%$ greater reduction with GTS $400 \mathrm{mg} / \mathrm{kg}$ compared with GTS $100 \mathrm{mg} / \mathrm{kg}$ ) than for the reduction of striatal DA release ( $31 \%$ greater reduction with GTS $400 \mathrm{mg} / \mathrm{kg}$ compared with GTS $100 \mathrm{mg} / \mathrm{kg}$ ). Although it is not certain whether the magnitude of locomotor activity changes proportionally to that of DA release, this finding suggests that mechanisms other than DA release inhibition may be involved in the behavioral effect of high-dose GTS. This idea is supported by our finding that high doses of GTS ( 400 and $800 \mathrm{mg} / \mathrm{kg}$ ) inhibited the in vivo binding of $\left[{ }^{3} \mathrm{H}\right]$ raclopride to DA $\mathrm{D}_{2}$ receptors in the striatum. Also, it has been reported that GTS showed an antidopaminergic action at postsynaptic DA receptor sites by inhibiting apomorphine-induced climbing behavior (Kim et al, 1996a). In addition, high-dose ginseng 
extract inhibited adenylate cyclase activity in rat brain tissues (Petkov, 1978). Taken together, it is likely that GTS may act on $\mathrm{DA} \mathrm{D}_{2}$ receptors as an antagonist. The results of the present study suggest that GTS acts not only on dopaminergic neurons directly or indirectly to prevent nicotine-induced DA release but also postsynaptically by binding to $\mathrm{DA} \mathrm{D}_{2}$ receptors. This may explain the blocking effect of GTS on behavioral activation induced by nicotine.

As nicotine increases DA release by stimulating nicotinic acetylcholine receptors (nAChRs) located in the terminal and somatodendritic regions of the dopaminergic neurons (Marshall et al, 1997; Mifsud et al, 1989; Wonnacott et al, 1990; Nisell et al, 1994a, b), it is possible that GTS inhibits $\mathrm{DA}$ release by acting on $\mathrm{nAChRs}$ in the dopaminergic neurons. Supporting this idea, it has been reported that ginseng saponins reduced acetylcholine-evoked $\mathrm{Na}^{+}$influx and catecholamine secretion in bovine adrenal chromaffin cells, but did not affect catecholamine secretion induced by high $\mathrm{K}^{+}$(an activator of voltage-sensitive $\mathrm{Ca}^{2+}$ channels) or veratridine (an activator of voltage-sensitive $\mathrm{Na}^{+}$ channels) (Tachikawa et al, 1995). Also, it has been shown that GTS had no effect on DA release induced by intrastriatal infusion of high $\mathrm{K}^{+}$solution (Shim et al, 2000). These data suggest that GTS blocks the nAChRs or the receptor-operated $\mathrm{Na}^{+}$channels (but not voltagesensitive $\mathrm{Na}^{+}$and $\mathrm{Ca}^{2+}$ channels), inhibit $\mathrm{Na}^{+}$influx through the channels and consequently reduce both $\mathrm{Ca}^{2+}$ influx and DA release. In our preliminary studies, GTS did not affect the binding of $\left[{ }^{3} \mathrm{H}\right]$ nicotine to rat striatal membranes. This suggests that GTS may act on the receptor-operated ion channels rather than $\mathrm{nAChRs}$ or on the nAChR subtypes not labeled by $\left[{ }^{3} \mathrm{H}\right]$ nicotine. However, there is possibility that GTS acts on GABAergic and glutamatergic neurons, receptors of the neurotransmitters, or nAChRs located in these neurons, because these neurons interact with dopaminergic neurons in the mesoaccumbens and nigrostriatal systems to modulate DA release (Mansvelder and McGehee, 2002; Smolders et al, 1995). Indeed, several studies provided evidence that ginsenosides may regulate the $\mathrm{GABA}_{\mathrm{A}}$ receptor. For example, ginsenosides differentially regulated $\left[{ }^{3} \mathrm{H}\right]$ flunitrazepam and $\left[{ }^{3} \mathrm{H}\right]$ muscimol binding to the $\mathrm{GABA}_{\mathrm{A}}$ receptor in a rat brain membrane fraction (Kimura et al, 1994). Prolonged infusion with ginsenoside $\mathrm{Rc}$ but not with ginsenoside $\mathrm{Rg}_{1}$ into rat brain elevated $\left[{ }^{3} \mathrm{H}\right]$ muscimol binding to the $\mathrm{GABA}_{\mathrm{A}}$ receptor in a region-specific manner (Kim et al, 2001). In addition, Tsang et al (1985) reported that ginseng saponins inhibited uptake of GABA in rat brain synaptosomes. Also, it has been shown that ginsenosides attenuate glutamateinduced injury of neuronal and non-neuronal cells in the brain (Abe et al, 1994; Seong et al, 1995; Kim et al, 2002).

Ginseng saponins were able to attenuate behavioral activation induced not only by nicotine but also by other psychostimulants, such as cocaine (Kim et al, 1995a), methamphetamine (Tokuyama et al, 1992), and morphine (Kim et al, 1995b). Interestingly, we found that GTS also inhibited cocaine-induced increase in extracellular DA without affecting $\left[{ }^{3} \mathrm{H}\right]$ WIN 35428 binding to the DA transporter in rat striatum (data not shown). In other words, GTS attenuated the behavioral and extracellular DA increasing effects of psychostimulants that behave with different mechanisms (ie, increasing DA release (nicotine) $v s$ blocking DA transporters (cocaine)). This suggests that GTS may act on the final common pathways of the negative feedback loop for the regulation of dopaminergic neurotransmission.

Drug treatments affecting dopaminergic transmission modulate the expression of Fos protein encoded by $c$-fos proto-oncogene in the striatum (Graybiel et al, 1990; Robertson et al, 1990; Herrera and Robertson, 1996; Moratalla et al, 1996). Acute nicotine elevates Fos expression in various brain regions, including dopaminergic target areas (Ren and Sagar, 1992; Matta et al, 1993; Pang et al, 1993; Kiba and Jayaraman, 1994; Panagis et al, 1996; Salminen et al, 1996; Valentine et al, 1996). In the present study, GTS decreased nicotine-induced Fos protein expression in the nucleus accumbens and striatum. This reflects the inhibition of nicotine-induced enhancement of dopaminergic transmission by GTS. From our results, the effect of GTS may be due in large measure to its inhibitory effect on $\mathrm{DA}$ release because $\mathrm{DA} \mathrm{D}_{1}$ receptor, but not $\mathrm{D}_{2}$ receptor, mediates nicotine-induced Fos expression in the striatum and nucleus accumbens (Kiba and Jayaraman, 1994; Nisell et al, 1997; Svenningsson and Le Moine, 2002). In addition, GTS may exert an inhibitory effect on DA $D_{1}$ receptors, which should be investigated by further studies. We found that GTS did not affect resting levels of Fos expression. This is in line with the finding that GTS had no effect on resting levels of extracellular DA.

In this study, for the microdialysis and locomotor activity experiments, nicotine was perfused via the microdialysis probe in a concentration of $10 \mathrm{mM}$ at a rate of $1.5 \mu \mathrm{l} / \mathrm{min}$ (ie, in a dose of $15 \mathrm{nmol} / \mathrm{min}$ ). Previous microdialysis studies have shown that local perfusion of $1-10 \mathrm{mM}(1.5-40 \mathrm{nmol} /$ min) nicotine elicited a reliable and consistent increase in DA content of the striatal dialysate samples (Marshall et al, 1997; Lecca et al, 2000; Shim et al, 2001). Lecca et al (2000) reported that perfusion of $0.2 \mathrm{nmol} / \mathrm{min}$ nicotine failed to increase DA content, while perfusion of 2 or $10 \mathrm{nmol} / \mathrm{min}$ nicotine significantly enhanced DA content in striatal dialysate samples. Also, in our pilot studies, 5 or $10 \mathrm{mM}$ nicotine produced a stable and reliable increase in both DA release and locomotor activity. Thus, we used $10 \mathrm{mM}$ nicotine in our experiments.

A major limitation of this study is that more direct measures of nicotine reinforcement, such as nicotine selfadministration and nicotine-induced conditioned place preference, were not employed to assess the effects of GTS. The effects of GTS on those measures of nicotine reinforcement should be examined before drawing definitive conclusions on the potential effects of GTS on nicotine intake. To our knowledge, there is no clinical trial evidence or anecdotal report on the relationship between ginseng use and decreased tobacco consumption. Obviously, clinical studies for the elucidation of the efficacy of ginseng in smoking cessation treatment should be performed in the future.

In conclusion, the results of the present study suggest that GTS acts not only on dopaminergic neurons directly or indirectly to prevent nicotine-induced DA release, but also postsynaptically by binding to $\mathrm{DA} \mathrm{D}_{2}$ receptors. This may explain the blocking effect of GTS on behavioral activation induced by nicotine and conceivably by other psychostimulants. Our data raise the possibility that GTS, by 
attenuating nicotine-induced enhancement of dopaminergic transmission, may prove to be a useful therapeutic agent for nicotine addiction and warrant further investigation on its effect on nicotine's rewarding property.

\section{ACKNOWLEDGEMENTS}

This study was supported by grants from the Brain Research Center of the 21st Century Frontier Research Program funded by the Ministry of Science and Technology of Republic of Korea (M103KV010016-04K2201-01630) and the Biomedical Brain Research Center, Ministry of Health and Welfare, Republic of Korea (01-PJ8-PG6-01NE01-0003).

\section{REFERENCES}

Abe K, Cho SI, Kitagawa I, Nishiyama N, Saito H (1994). Differential effects of ginsenoside $\mathrm{Rb} 1$ and malonylginsenoside $\mathrm{Rb} 1$ on long-term potentiation in the dentate gyrus of rats. Brain Res 649: 7-11.

Ando T, Tanaka O, Shibata S (1971). Chemical studies on the saponins and sapogenins of ginseng and related crude drugs. Syoyakugaku Zasshi 25: 28-32.

Benwell MEM, Balfour DJK (1992). The effects of acute and repeated nicotine treatment on nucleus accumbens dopamine and locomotor activity. Br J Pharmacol 105: 849-856.

Benwell MEM, Balfour DJK (1994). Comparison of the effects of constant nicotine infusion on nucleus accumbens and striatal dopamine responses to acute nicotine. In: Clarke PBS, Quik M, Thurau K, Adlkofer F (eds). The Effects of Nicotine on Biological Systems II. Birkhauser Verlag: Basel. p 66.

Corrigall WA, Franklin KB, Coen KM, Clarke PB (1992). The mesolimbic dopamine system is implicated in the reinforcing effects of nicotine. Psychopharmacology 107: 285-289.

Damsma G, Day J, Fibiger HC (1989). Lack of tolerance to nicotineinduced dopamine release in the nucleus accumbens. Eur $J$ Pharmacol 168: 363-368.

Di Chiara G, Imperato A (1988). Drugs abused by humans preferentially increase synaptic dopamine concentrations in the mesolimbic system of freely moving rats. Proc Natl Acad Sci USA 85: 5274-5278.

Graybiel AM, Moratalla R, Robertson HA (1990). Amphetamine and cocaine induce drug-specific activation of the $c$-fos gene in striosome-matrix and limbic subdivisions of the striatum. Proc Natl Acad Sci USA 87: 6912-6916.

Henningfield JE, Heishman SJ (1995). The addictive role of nicotine in tobacco use. Psychopharmacology 117: 11-13.

Herrera DG, Robertson HA (1996). Activation of $c$-fos in the brain. Prog Neurobiol 50: 83-107.

Imperato A, Mulas A, Di Chiara G (1986). Nicotine preferentially stimulates dopamine release in the limbic system of freely moving rats. Eur J Pharmacol 132: 337-338.

Kiba H, Jayaraman A (1994). Nicotine induced $c$-fos expression in the striatum is mediated mostly by dopamine D1-receptor and is dependent on NMDA stimulation. Mol Brain Res 23: 1-13.

Kim HS, Hwang SL, Nah SY, Oh S (2001). Changes of $\left[{ }^{3} \mathrm{H}\right] \mathrm{MK}-801$, $\left[{ }^{3} \mathrm{H}\right]$ muscimol and $\left[{ }^{3} \mathrm{H}\right]$ flunitrazepam binding in rat brain by the prolonged ventricular infusion of ginsenoside Rc and Rg1. Pharmacol Res 43: 473-479.

Kim HS, Jang CG, Oh KW, Seong YH, Rheu HM, Cho DH et al (1996a). Effect of ginseng total saponin on cocaine-induced hyperactivity and conditioned place preference in mice. Pharmacol Biochem Behav 53: 185-190.

Kim HS, Jang CG, Park WK, Oh KW, Rheu HM, Cho DH et al (1996b). Blockade by ginseng total saponin of methampheta- mine-induced hyperactivity and conditioned place preference in mice. Gen Pharmacol 27: 199-204.

Kim HS, Kang JG, Oh KW (1995a). Inhibition by ginseng total saponin of the development of morphine reverse tolerance and dopamine receptor supersensitivity in mice. Gen Pharmacol 26: 1071-1076.

Kim HS, Kang JG, Seong YH, Nam KY, Oh KW (1995b). Blockade by ginseng total saponin of the development of cocaine induced reverse tolerance and dopamine receptor supersensitivity in mice. Pharmacol Biochem Behav 50: 23-27.

Kim HS, Kim KS (1999). Inhibitory effects of ginseng total saponin on nicotine-induced hyperactivity, reverse tolerance and dopamine receptor supersensitivity. Behav Brain Res 103: 55-61.

Kim S, Ahn K, Oh TH, Nah SY, Rhim H (2002). Inhibitory effect of ginsenosides on NMDA receptor-mediated signals in rat hippocampal neurons. Biochem Biophys Res Commun 296: 247-254.

Kimura T, Saunders PA, Kim HS, Rheu HM, Oh KW, Ho IK (1994). Interactions of ginsenosides with ligand-bindings of $\mathrm{GABA}_{\mathrm{A}}$ and $\mathrm{GABA}_{\mathrm{B}}$ receptors. Gen Pharmacol 25: 193-199.

Ko SR, Kim SC, Choi KJ (1992). Extract yields and saponin contents of red ginseng extracts prepared with various concentrations of ethanol. Kor J Pharmacogn 23: 24-28.

Lecca D, Shim I, Costa E, Javaid JI (2000). Striatal application of nicotine, but not of lobeline, attenuates dopamine release in freely moving rats. Neuropharmacology 39: 88-98.

Lidow MS, Goldman-Rakic PS, Rakic P, Innis RB (1989). Dopamine $\mathrm{D}_{2}$ receptors in the cerebral cortex: distribution and pharmacological characterization with $\left[{ }^{3} \mathrm{H}\right]$ raclopride. Proc Natl Acad Sci USA 86: 6412-6416.

Mansvelder HD, McGehee DS (2002). Cellular and synaptic mechanisms of nicotine addiction. J Neurobiol 53: 606-617.

Marshall DL, Redfern PH, Wonnacott S (1997). Presynaptic nicotine modulation of dopamine release in the three ascending pathway studied by in vivo microdialysis: comparison of naive and chronic nicotine-treated rats. J Neurochem 68: 1511-1519.

Matta SG, Foster CA, Sharp BM (1993). Nicotine stimulates the expression of cFos protein in the parvocellular paraventricular nucleus and brainstem catecholaminergic regions. Endocrinology 132: 2149-2156.

Mifsud JC, Hernandez L, Hoebel BG (1989). Nicotine infused into the nucleus accumbens increases synaptic dopamine as measured by in vivo microdialysis. Brain Res 478: 365-367.

Mirza NR, Pei Q, Stolerman IP, Zetterstrom TS (1996). The nicotinic receptor agonists (-)-nicotine and isoarecolone differ in their effects on dopamine release in the nucleus accumbens. Eur J Pharmacol 295: 207-210.

Moratalla R, Elibol B, Vallejo M, Graybiel AM (1996). Networklevel changes in expression of inducible Fos-Jun proteins in the striatum during chronic cocaine treatment and withdrawal. Neuron 17: 147-156.

Nisell M, Nomikos GG, Svensson TH (1994a). Systemic nicotineinduced dopamine release in the rat nucleus accumbens is regulated by nicotinic receptors in the ventral tegmental area. Synapse 16: 36-44.

Nisell M, Nomikos GG, Chergui K, Grillner P, Svensson TH (1997). Chronic nicotine enhances basal and nicotine-induced Fos immunoreactivity preferentially in the medial prefrontal cortex of the rat. Neuropsychopharmacology 17: 151-161.

Nisell M, Nomikos GG, Svensson TH (1994b). Infusion of nicotine in the ventral tegmental area or the nucleus accumbens of the rat differentially affects accumbal dopamine release. Pharmacol Toxicol 75: 348-352.

Panagis G, Nisell M, Nomikos GG, Chergui K, Svensson TH (1996). Nicotine injections into the ventral tegmental area increase locomotion and Fos-like immunostaining in the nucleus accumbens of the rat. Brain Res 730: 133-142. 
Pang Y, Kiba H, Jayaraman A (1993). Acute nicotine injections induce $c$-fos mostly in non-dopaminergic neurons of the midbrain of the rat. Mol Brain Res 20: 162-170.

Parreno A, Saraza ML, Subero C (1985). A new stabilimeter for small laboratory animals. Physiol Behav 34: 475-478.

Paxinos G, Watson C (1986). The rat brain in stereotaxic coordinates, 2nd ed. Academic Press: New York.

Petkov VW (1978). Effects of ginseng on the brain biogenic monoamines and $3^{\prime}, 5^{\prime}$-AMP system: experiments on rats. Arzneim-Forsch 28: 388-393.

Pontieri FE, Francesco E, Tanda G, Francesco O, Di Chiara G (1996). Effects of nicotine on the nucleus accumbens and similarity to those of addictive drugs. Nature 382: 255-257.

Ren T, Sagar SM (1992). Induction of $c$-fos immunostaining in the rat brain after the systemic administration of nicotine. Brain Res Bull 29: 589-597.

Robertson GS, Vincent SR, Fibinger HC (1990). Striatonigral projection neurons contain D1 dopamine receptor-activated c-fos. Brain Res 523: 288-290.

Salminen O, Lahtinen S, Ahtee L (1996). Expression of Fos protein in various rat brain areas following acute nicotine and diazepam. Pharmacol Biochem Behav 54: 241-248.

Seong YH, Shin CS, Kim HS, Baba A (1995). Inhibitory effect of ginseng total saponins on glutamate-induced swelling of cultured astrocytes. Biol Pharm Bull 18: 1776-1778.

Shim I, Javaid JI, Kim SE (2000). Effect of ginseng total saponin on extracellular dopamine release elicited by local infusion of nicotine into the striatum of freely moving rats. Planta Med 66: 705-708.

Shim I, Javaid JI, Wirtshafter D, Jang SY, Shin KH, Lee HJ et al (2001). Nicotine-induced behavioral sensitization is associated with extracellular dopamine release and expression of c-Fos in the striatum and nucleus accumbens of the rat. Behav Brain Res 121: 137-147.
Smolders I, De Klippel N, Sarre S, Ebinger G, Michotte Y (1995). Tonic GABA-ergic modulation of striatal dopamine release studied by in vivo microdialysis in the freely moving rat. Eur J Pharmacol 284: 83-91.

Svenningsson P, Le Moine C (2002). Dopamine D1/5 receptor stimulation induces c-fos expression in the subthalamic nucleus: possible involvement of local D5 receptors. Eur J Neurosci 15: 133-142.

Tachikawa E, Kudo K, Kashimoto T, Takahashi E (1995). Ginseng saponins reduce acetylcholine-evoked $\mathrm{Na}^{+}$influx and catecholamine secretion in bovine adrenal chromaffin cells. J Pharmacol Exp Ther 273: 629-636.

Tokuyama S, Oh KW, Kim HS, Takahashi M, Kaneto H (1992). Blockade by ginseng extract of the development of reverse tolerance to the ambulation-accelerating effect of methaphetamine in mice. Jpn J Pharmacol 59: 423-425.

Toth E, Sershen H, Hashim A, Vizi ES, Lajtha A (1992). Effect of nicotine on extracellular levels of neurotransmitters assessed by microdialysis in various brain regions: role of glutamic acid. Neurochem Res 17: 265-271.

Tsang D, Yeung HW, Tso WW, Peck H (1985). Ginseng saponins: influence on neurotransmitter uptake in rat brain synaptosomes. Planta Med 3: 221-224.

Valentine JD, Matta SG, Sharp BM (1996). Nicotine-induced cFos expression in the hypothalamic paraventricular nucleus is dependent on brainstem effects: correlations with cFos in catecholaminergic and noncatecholaminergic neurons in the nucleus tractus solitarius. Endocrinology 137: 622-630.

Wonnacott S, Drasdo A, Sanderson E, Rowell P (1990). Presynaptic nicotinic receptors and modulation of transmitter release. In: Bock G, Marsh J (eds). The Biology of Nicotine Dependence. John Wiley \& Sons: Chichester. pp 87-101. 